\title{
Occurs with Overdose
}

National Cancer Institute

\section{Source}

National Cancer Institute. Occurs with Overdose. NCI Thesaurus. Code C82548.

An indication or description that an event occurs concurrently with a substance overdose. 